\title{
Nepalese Foreign Trade: Growth, Composition, and Direction
}

\author{
Khubi Ram Acharya, MPhil \\ Lecturer \\ Nepal Commerce Campus, T.U.
}

\begin{abstract}
The objective of this article is to study and analyze the growth, composition, and direction of the Nepalese foreign trade. This is descriptive a study that uses secondary sources of information. The analysis is based on simple statistical tools like ratio and percent. This study finds the very low export performance of Nepal. This is creating the problem of rapidly increasing trade deficit. Nepal is also unable to diversify its trade in terms of countries and commodities. The major causes of increasing trade deficit are low export, and high import, low-quality products, improper trade policy, higher cost of production, lack of publicity and advertisement, low production, slow industrial development, lack of trade diversification, etc. Nepal can reduce its trade deficit by diversification of its trade in terms of commodities and countries.
\end{abstract}

Keywords: Foreign Trade, Export, Import, Competitiveness

\section{Introduction}

In the modern age, all economies are dependent economies. All the economies import and export goods and services. A country imports those goods, which are not available in the country and exports those goods, which have excess supply in the country. International trade has played a very important role in the economic development of countries. The modernization of the backward countries would not be possible if there was no international trade. It promotes economic development by improving competitive capacity, expanding market, and providing modern technology and machinery for the industrial and agricultural sector. Therefore, it is also considered as the vehicle of economic development (Silwal, 2008). Before 1951 AD, Nepal's foreign trade was only with India and Tibet. But after 1951 AD, Nepal's trade relation expanded with many other countries of the world like Japan, the USA, Germany, Malaysia, Singapore, Thailand, Kuwait, France, Bangladesh, Spain, etc. Nepal's foreign trade is rapidly increasing but with the increase in the total volume of trade, the trade deficit is also increasing (Kafle, 2017).

\section{Problem and Issue}

In Nepal, the trade deficit is continuously increasing because of very few goods to export. Most of the exports are of the raw material in nature with large volume and low profitable value, although Nepal's export has changed from agriculture goods in the 1980s to manufactured goods after 1990s. As compared to imports, the rate of export is decreasing over time. The flow of remittance has increased the imports especially of vehicles, electronics, petroleum products, etc. whereas; instability and insecurity have decreased the export. Furthermore, the abolishment of export quota in 2005 further worsened the trade gap.

Nepal is one of the most liberalized and trade-dependent economies in South Asia. The process of economic liberalization started in 1985 and geared up after 1990. By 2004 (the year of WTO membership), Nepal continued to broaden the openness and pushed down tariff walls and other kinds of import restrictions. 
However, when the domestic manufacturing sector is in its infant stage and the country is foreign-resource dependent for development finance, the costs of liberalization may outweigh its benefits (Silwal, 2008). Thus, Nepal's main issue of foreign trade is increasing trade deficit even after various issues and policies.

\section{Scope and Limitations}

The focus of this study is to assess the trade performance of Nepal. However, the study has some limitations, which are as follows:

i. This study includes only merchandise trade in Nepal.

ii. The findings of this study cannot be generalized to all developing countries because of their diverse characteristics.

iii. The reliability of this study depends on the reliability of secondary data.

iv. The study covers the period from the year 1990/91 to 2017/18.

\section{Objective}

The general objective of the study is to analyze Nepalese foreign trade but the specific objectives of the study are to:

- $\quad$ analyze the growth trend of Nepalese foreign trade

- $\quad$ assess the composition of Nepalese foreign trade

- $\quad$ identify the direction of the Nepalese foreign trade.

\section{Literature Review}

In the mid-1960s, Nepal adopted export diversification and import substitution strategies. In 1977, the government introduced the Duel Exchange Rate System, which was modified in 1978. In 1981, a cash subsidy program was introduced to promote exports. Other important measures adopted by the government include the Dual Exchange Rate System of 1977, cash subsidy program, duty exemption on export commodities, special financial arrangement for production and export, simplification of licensing and customs procedures, and introduction of new industry and trade-related acts, etc. (IIDS, 1996).

Santosh-Paulino and Thirlwall (2004) have used panel data analysis to estimate the effect of trade liberalization on export trade performance, import trade performance, the balance of trade and the balance of payments for a sample of 22 developing countries that have adopted trade liberalization policies since the mid-1970s. They found that liberalization stimulated export trade performance but raised import trade performance by more, leading to a worsening of the balance of trade and payments.

Chaudhary (2011) has studied the sensitivity or impact of trade openness in Nepal using various aspects of trade openness like vulnerability, sensitivity, and harmonization as well as the impact of trade openness on per capita income growth for the period of 1990/91 to 2010/11. The results suggest that overall trade openness vulnerability of Nepal is low with the manufacturing and service sector being more open in comparison to the agriculture and energy sectors. While there is a strong performance of the openness growth rate for the review period, the average ratio of the openness growth and per capita income growth both with nominal income, is negative. The results indicate a low sensitivity of per capita income growth to the trade openness growth. The findings reveal that the productivity benefits from additional trade are higher for the trading partners of Nepal than themselves. He argues that Nepal has liberalized trade without introducing appropriate internal policies and institutions.

Ghani (2011) examined the impact of trade liberalization on the merchandise trade balance for a sample of developing countries that have adopted trade liberalization policies. The impact is differentiated according to the destinations and origins of the exports and imports, whether they are developing or industrial countries. This is important as one of the arguments for protection is based on the assumption of asymmetry in the elasticities of products traded between developing and industrial countries, and this asymmetry leads 
Vol. 4, No. 1

to disparity in economic growth. The paper shows that the impact on the merchandise trade balance differs between the two groups of trading partners; there is weak evidence that the trade balance worsens (increase in deficit) for trade with developing countries, but the trade balance improves (increase in surplus) for trade with industrial countries.

Upreti (2012) has analyzed the effect of trade liberalization on Nepalese international trade both in pre and post-liberalization periods using Philip Hanson Fully Modified Ordinary Least Square Cointegration Model. The main empirical outcome of his study is that there is no significant positive impact of trade liberalization on export, import and trade balance both in the pre-liberalization and post-liberalization period both in the long-run and short-run. The study also shows no positive impact of trade liberalization on economic growth and balance of payment.

\section{Research Methodology}

The study is descriptive in nature. It is based on secondary data. In identifying the growth trend, composition and diversification of Nepalese foreign trade, data have been collected after the liberalization of international trade in Nepal. The time period selected is from 1990/91 to 20116/17. Since the study is based on secondary sources, data have been collected from the various publications of the Ministry of Finance. Based on the problem, issues, and objectives, detailed information has been collected to describe and analyze the research objectives. The research is based on quantitative data. The description of the situation of the Nepalese foreign trade and trade performance is all in quantitative data. Simple statistical tools: ratios and percentages have been to analyze data.

\section{Results}

This section is concerned with the outcome of the article. Thus, considering the nature of the data, we have divided the entire outcome into the three sections as follows:

\section{Growth of Nepalese Foreign Trade}

Before 1951 AD, Nepal's trade relation was only with India and Tibet. The trade relation of Nepal expanded with other many countries after the decline of the Rana regime. Nowadays, the foreign trade of Nepal has expanded rapidly with many countries of the world and the volume of trade has also increased. During the fiscal year 1956/57, the total export of Nepal was equivalent to Rs. 9.5 crore and the total import was equivalent to Rs. 17 crore. The total volume of trade was equivalent to Rs. 26.5 crore. But nowadays, it has increased thousands of times. Table 1shows the growth trend of the Nepalese foreign trade.

Table 1: Growth of Nepalese Foreign Trade

\begin{tabular}{|ccccc|}
\hline Fiscal Year & Export & Import & Volume of Trade & Trade Balance \\
$1990 / 91$ & 1370.65 & 3194.00 & 4564.65 & -1823.35 \\
$2000 / 01$ & 5565.41 & 11568.72 & 17134.13 & -6003.31 \\
$2011 / 12$ & 7426.10 & 46166.80 & 53592.90 & -38740.70 \\
$2012 / 13$ & 7691.70 & 55674.00 & 63365.70 & -47982.30 \\
$2013 / 14$ & 9199.10 & 71436.60 & 80632.70 & -62237.50 \\
$2014 / 15$ & 8531.91 & 77468.40 & 86000.00 & -68936.50 \\
$2015 / 16$ & 7011.7 & 77359.9 & 84371.6 & -70348.2 \\
$2016 / 17$ & 7304.9 & 99011.3 & 106316.2 & -91706.4 \\
\hline
\end{tabular}

Source: Economic Survey 1993, 2003 and 2018

Table 1 shows the growth trend of the Nepalese foreign trade since the fiscal year 1990/91. In the $\sim 93 \sim$ 
fiscal year 1990/91, Nepal's export was equivalent to Rs. 1370.65 crore, the import was equivalent to Rs. 3194 crore; the total volume of trade was 4564.65 crore, and the trade deficit was Rs. 1823.35 crore. In the fiscal year 2016/17, the total export was equivalent to Rs. 7304.9 crore; the total import was equivalent to Rs. 99011.3 crore; the volume of trade was Rs. 106316.2 crore and the trade deficit was Rs. 91706.4 crore. This shows that Nepal's export, import, the volume of trade, and trade deficit are increasing rapidly. But the rate of increase in imports is higher than the rate of increase in export. Consequently, Nepal's trade deficit is very high and increasing rapidly every year. The persistent deficit in foreign trade is due to the low production of export-oriented goods and higher import of consumer goods. In order to reduce this deficit, the production of competitive goods should be increased, which will help to increase export and reduce import.

\section{Composition of Nepalese Foreign Trade}

The composition of trade refers to the composition of imports and export. A study of changes in the composition of foreign trade helps to analyze the economic progress of the country. For example, if the import of manufacturing goods is declining and the export of these goods is increasing, it is considered as the better speed of the economic development or progress in the country. Table 2 shows the composition of the Nepalese foreign trade in the fiscal year 2016/17. In Nepal, commodities traded with foreign countries are classified according to the Standard International Trade Classification (SITC). The SITC includes goods imported and exported in the ten headings.

Table 2. Commodity Trade by SITC Group: FY 2016/17

\begin{tabular}{|cllcccc|}
\hline \multirow{2}{*}{ S.N. } & \multirow{2}{*}{ SITC Group } & \multicolumn{2}{c}{ Exports } & \multicolumn{2}{c|}{ Imports } \\
\cline { 3 - 6 } & & Rs. in crore & In percentage & Rs. in crore & In percentage \\
\hline 1 & Food and live animals & 1830.6 & 25.1 & 13062.3 & 13.2 \\
2 & Tobacco and beverage & 25 & 0.3 & 801.1 & 0.8 \\
3 & Crude materials and inedible & 299.3 & 4.1 & 3665.5 & 3.7 \\
4 & Minerals, fuels, and lubricants & 0 & 0.0 & 14137.9 & 14.3 \\
5 & Animals and vegetable oil and fats & 15.9 & 0.2 & 3015.6 & 3.0 \\
6 & Chemical and drugs & 442.1 & 6.1 & 10285.7 & 10.4 \\
7 & Classified by materials & 3445.3 & 47.2 & 21089.9 & 21.3 \\
8 & Machinery and transport equipment & 20.5 & 0.3 & 24700.7 & 24.9 \\
9 & Misc. manufactured articles & 1226.1 & 16.8 & 5509.6 & 5.6 \\
10 & Not classified & 0 & 0.0 & 2743.2 & 2.8 \\
\hline & Total & 7304.9 & 100.0 & 99011.3 & 100 \\
\hline
\end{tabular}

Source: Economic Survey, 2018 headings:

The composition of Nepal's foreign trade can be explained by dividing into the following two

Composition of export: The major exportable goods of Nepal are woolen goods, carpets (hand-knotted woolen), Nepalese paper and paper products, readymade garments, handicrafts, ornaments, pashmina, pulses, cardamom, medical herbs, etc. These goods are exported to India and other countries like the USA, China, Germany, UK, etc. Table 2 shows the values of export of Nepal by SITC group for the fiscal year 2016/17. From the table, it is clear that the value of 'classified by materials' had occupied the first position 
Vol. 4 , No. 1

$(47.2 \%)$ in the total export in the fiscal year 2016/17. Similarly, the value of 'food and live animals' had occupied second position (25.1\%) and the value of 'miscellaneous manufactured articles' had occupied the third position (16.8\%) in the total export in the fiscal year 2016/17.

Composition of import: The major goods imported in Nepal are various finished goods, semi-finished goods, raw materials of industry, machinery, equipment, chemical fertilizers, petroleum products, gold, electrical goods, readymade garments, etc. Table 2 shows the values of import of Nepal by the SITC group for the fiscal year 2016/17. From the table, it is clear that the value of 'machinery and transport equipment' had occupied the first position (i.e. 24.9\%) in the fiscal year 2016/17. Similarly, the second position (21.3\%) was occupied by 'classified by materials' and the third position $(13.2 \%)$ was occupied by 'food and live animals'.

\section{Direction of Foreign Trade of Nepal}

Before 1951 AD, Nepal's foreign trade was limited only with India and Tibet. The trade with India formed 95 percent and the remaining trade was with Tibet. The trade with overseas countries was almost nil. The major reasons behind the concentration of Nepalese trade with India were: Nepal bordering by India, open border with India, and similarities in language, culture, religion, tradition, etc. But nowadays, Nepal's trade relation is with many overseas countries besides India and China. But India is still a major trading partner of Nepal. In the fiscal year 1974/75, Nepal's 82.2 percentage trade was with India and the trade with other countries was only 17.8 percent. In the fiscal year 1984/85, the trade with India was reduced to 52.4 percent. In the fiscal year 1990/91, the trade with India was 52.5 percent (Pant, 1994). Nepal's trade dependency with India was declining until the fiscal year 1996/97. But in the later years, the share of trade with India has increased rapidly.

The direction of the Nepalese foreign trade is presented in Table 3.

Table 3: Direction of Foreign Trade of Nepal (Rs. in Crore)

\begin{tabular}{|l|c|c|c|c|c|}
\hline Description & $2012 / 13$ & $2013 / 14$ & $2014 / 15$ & $2015 / 16$ & $2016 / 17$ \\
Export & 7691.70 & 9199.10 & 8531.91 & 7011.7 & 7011.7 \\
India & 5100.00 & 5961.40 & 5586.46 & 3949.4 & 4144.9 \\
China & 208.6 & 284.1 & 223.0 & 168.2 & 170.1 \\
Other countries & 2383.2 & 2953.7 & 2722.5 & 2894.2 & 2989.8 \\
Import & 55674.00 & 71436.60 & 77468.42 & 77359.9 & 99011.3 \\
India & 36703.10 & 47794.70 & 49165.99 & 47721.3 & 63367.0 \\
China & 6245.1 & 7331.9 & 10016.6 & 11569.4 & 12724.5 \\
Other countries & 12725.8 & 16310.0 & 18286.2 & 18069.2 & 22919.9 \\
Total Trade & 63365.8 & 80635.7 & 86000.3 & 84371.6 & 1063316.2 \\
India & 41803.1 & 53756.1 & 54752.1 & 51670.6 & 67511.9 \\
China & 6453.7 & 7615.9 & 10239.6 & 11737.6 & 12894.7 \\
Other countries & 15108.9 & 19263.7 & 21008.7 & 20963.4 & 25909.7 \\
Total Trade Share (Percentage) & 100 & 100 & 100 & 100 & 100 \\
India & 66.0 & 66.7 & 63.7 & 61.2 & 63.5 \\
China & 10.2 & 9.4 & 11.9 & 13.9 & 12.1 \\
Other countries & 23.8 & 23.9 & 24.4 & 24.8 & 24.4 \\
\hline
\end{tabular}

Source: Economic Survey, 2018 
Table 3 shows the direction of the Nepalese foreign trade since the fiscal year 2012/13 to 2016/17. From the table, it is clear that Nepal's major trade partner is India. Nepal's more than 60 percent of the total trade is with India. It shows that Nepal has not been very successful in the field of country-wise trade diversification. Although, the share of trade with India for the last three fiscal years is declining and share with China and other countries is increasing. Other countries include the USA, Germany, Japan, UK, France, Italy, Spain, Switzerland, Belgium, etc. Besides India and China, Nepalese products are exported to the USA, Germany, Japan, Bangladesh, the UK, France, Italy, Spain, Switzerland, Belgium, etc. Similarly, besides India and China, Nepal imports from Singapore, UK, UAE, Malaysia, Kuwait, etc. Nepal has also not been successful in the commodity-wise trade diversification. Nepal's more than 90 percent foreign exchange earnings from commodity exports that come from merely seven commodities: readymade garment, carpet, pulses, handicrafts, leather, medicinal herbs, and paper products. In recent years, the export of these products is also declining.

\section{Conclusion}

Because of low export performance, Nepal is facing the problem of rapidly increasing trade deficit. Nepal is also unable to diversify its trade in terms of countries and commodities. The major causes of Nepal's increasing trade deficit are landlockedness, low export and high import, low quality goods, improper trade policy, higher cost of production, lack of publicity and advertisement, low production, slow industrial development, lack of trade diversification, etc. Until and unless, Nepal increases its trade competitiveness adopting different policies, it cannot reduce its ever-increasing trade deficit. Nepal should also improve its trade structure in terms of commodities and destination.

\section{References}

Chaudhari, S. K. (2011). Sensitivity of the trade openness in Nepal. NRB Economic Review. Volume 23, No2. Kathmandu: Nepal Rastra Bank.

Ghani, Gairuzazmi M (2011). Impact of trade liberalisation on economic performance of OIC member countries. Journal of Economic Cooperation and Development. Vol.32 No.1

IIDS (1996). Impact of economic liberalization in Nepal. Kathmandu: IIDS

Kaflle, Arjun (2017). Nepal's foreign trade: present trends. IJLEMR. Vol.02 No.11

Karmacharya, Binod K. (2004). Performance of Nepalese foreign trade. In M.K. Dahal (ed.) Nepalese economics: Towards building a strong economic nation-state. Kathmandu: Central Department of Economics, TU and New Hira Books

Ministry of Finance (1993). Economic survey. Kathmandu: Ministry of Finance, GON Ministry of Finance (2003). Economic survey. Kathmandu: Ministry of Finance, GON Ministry of Finance (2018). Economic survey. Kathmandu: Ministry of Finance, GON

Pant, Bhubhanesh (1994). Trade and development: Nepal's experience. New Delhi: Oxford and IBH Publishing Cooperative Private Limited

Santos-Paulino, A. U. and Thirlwall, A. P. (2004). The Impact of trade liberalisation on exports, imports and the balance of payments of developing countries. Economic Journal, Vol. 114, No.

SAWTEE (2007). Policy research brief. Kathmandu: SAWTEE.

Silwal, Rajan(2008). The causes of trade deficit in Nepal. A research paper presented in partial fulfillment of the requirements obtaining the degree of M.A. in Development Studies in ISS

Upreti, Surendra Kumar (2012). Openness and Trade: Some Empirical Evidences from Nepalese International Trade . Pravaha: A Journal of Management, Vol. 18, No. 18 